\title{
Histochemical changes in mucus in duodenal ulceration
}

\author{
SHELAGH M MORRISSEY, P M WARD, A P JAYARAJ, \\ F I TOVEY, AND C G CLARK
}

From the Department of Physiology, Queen Elizabeth College, University of London, London; and Department of Surgery, University College Hospital Medical School, London

SUMmary In duodenal ulceration the Alcian blue staining acid mucosubstances in goblet cells are reduced and the goblet cells themselves disappear. At the same time periodic acid-Schiff (PAS) staining neutral mucosubstances appear in the cells of the surface epithelium. These changes have been measured quantitatively with the help of a Vickers M86/0010 Scanning and Integrated Microdensitometer. During healing the changes are reversed. It is suggested that these changes suggest a metaplasia towards a gastric type mucosa as a protective response to the presence of ulceration.

Mucosubstances in the human duodenum are normally secreted from goblet cells in the epithelium of the villi as well as from Brunners glands lying in the submucosa (Fig. 1). Histochemical studies have been carried out on epithelial mucins in the digestive tract of human subjects. ${ }^{1}$ They consist of both neutral and acidic mucins. There is very little information about the changes in duodenal mucins in duodenal ulceration. Gregory, Moshal, and Spitaels ${ }^{2}$ found that in duodenal ulceration goblet cells disappear and mucus appears within the surface epithelial cells with stunting of the villi, thus confirming the earlier work of James. ${ }^{3}$ Similarly earlier work by Jayaraj in 1968 (unpublished) had shown a reduction in goblet cells and acid mucopolysaccharides in duodenal ulceration. Quantitative histochemical studies on acid mucins in the small intestine of cystic fibrosis patients have been carried out by Morrissey and Tymvios ${ }^{4}$ but quantitative histochemical investigations in duodenal ulceration are not documented. This collaborative work was carried out in order to get quantitative values for any observed changes in the mucosubstances secreted by normal duodenum both before and after ulceration.

\section{Methods}

\section{SUBJECTS}

Endoscopic duodenal biopsy samples were obtained from Basingstoke District Hospital. The controls

\footnotetext{
Address for correspondence: Dr A P Jayaraj. Department of Surgery. University College Hospital Medical School. London WC1.

Received for publication 14 January 1983
}

were taken from patients who showed normal duodenum macroscopically which was also confirmed microscopically. The patients with healed ulcers had biopsies taken at check endoscopy after a 12 week course of cimetidine. The biopsies were taken close to the previous ulcer site. In those patients with ulceration the biopsy was taken from mucosa as close as possible to the ulcer. There were 10 control cases, eight cases with healed ulcers and eight with active ulcers.

All specimens obtained were fixed in buffered formol saline, embedded in paraffin wax and sectioned at $4 \mathrm{~nm}$. The sections were dewaxed and stained with Alcian blue (8GX) (AB) at pH 2.6 for acidic mucins and periodic acid-Schiff reagent (PAS) for neutral mucins. Other sections were stained with $\mathrm{AB}$ alone or PAS alone.

\section{QUANTITATIVE ESTIMATION OF MUCINS}

A Vickers M86/0010 Scanning and Integrated Microdensitometer was used on the Alcian blue stained sections and PAS stained sections. Goblet cell mucins were estimated by doing 40 random readings per slide. ${ }^{4}$ Readings were also taken randomly to give 40 readings from any PAS stained surface epithelium in a similar way. The mean value and standard error of mean were calculated.

\section{GOBLET CELL CQUNTS}

Thirty five millimetre slide photographs were taken of the stained sections at a uniform magnification and projected at a distance of 5.5 metres. A grid of 1600 square centimetres was placed over the projected picture of the whole section, and the total 


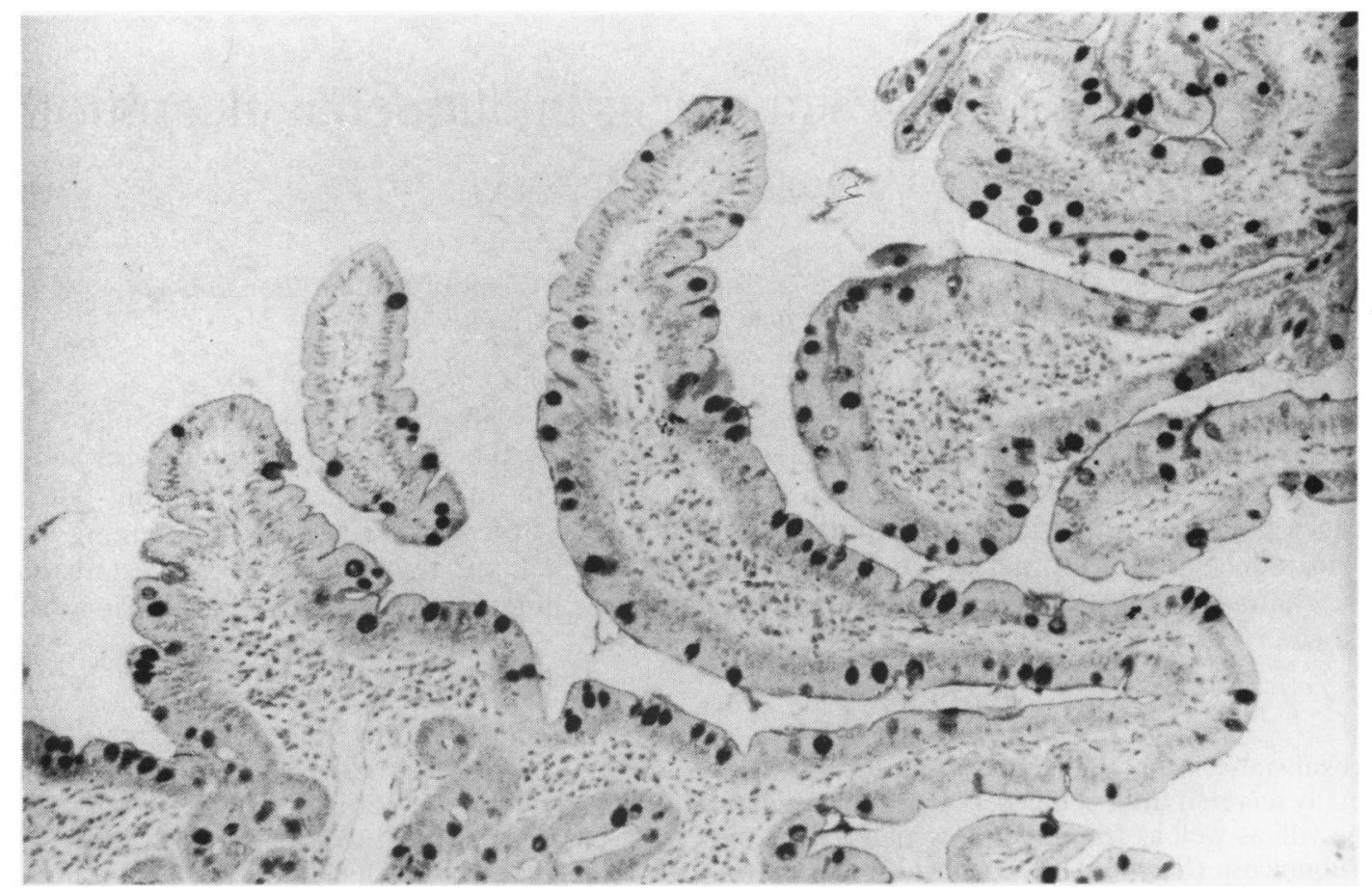

Fig. 1 Section of normal duodenum showing numerous alcian blue positive goblet cells. Alcian blue, PAS and haematoxylin $\times 100$.

number of cells falling within the area was counted.

\section{SURFACE EPITHELIAL STAINING IN RELATION TO} TOTAL LENGTH

A planimeter was used to find the total length of the surface epithelium on a given slide of the whole section. The length of PAS stained epithelium was expressed as a percentage of the total length measured.

\section{Discussion}

Histochemical investigations have been carried out on epithelial mucins in the digestive tract of human subjects, ${ }^{15-7}$ and the different histochemical properties of these mucins have been observed in different parts of the gastrointestinal tract. Epithelial glycoproteins in man are usually acidic because of their sialic acid residues ${ }^{8}$ or sulphated. ${ }^{9}$ Both sulphomucins and sialomucins have been studied in tracheal and bronchial mucosa, ${ }^{10}$ and in the sheep's colonic mucosa. ${ }^{11}$ A quantitative and histophotometric investigation of colonic epithelial mucins has been reported. ${ }^{12}$ Later studies on histochemical changes in gastric mucosubstances in patients with acute and chronic ulcer diseases have been reported by Cathcart et al. ${ }^{13}$ An estimation of the carbohydrate and ester sulphate content of mucosal biopsies was made by Andre et $a^{14}$ in health and in patients with duodenal ulcer. It is difficult, however, to relate a chemical analysis of components of glycoproteins with histochemical staining of mucosubstances within mucous secreting cells. A quantitative estimation of acid mucins in human intestinal goblet cells was first described by Morrissey and Tymvios ${ }^{4}$ using a Vickers M86 Scanning and Integrating Microdensitometer. In the study now presented the same method has been used to estimate quantitatively both acidic and neutral surface epithelial mucins in human duodenum and to study changes due to ulceration.

The goblet cell integrated density readings for neutral mucosubstances as stained by periodic Schiff reagent show no significant difference between the three groups - that is, the non-ulcer, ulcer and healed groups (Table 1) but there is a significant reduction in the acid Alcian blue mucosubstances in the ulcer group. Neutral mucosubstances, however, (PAS positive) appear in the surface epithelium with the progression of duodenal ulceration (Fig. 2, Table 3 and Table 4). In cases in which this PAS mucus appears, goblet cells are markedly decreased 
Table 1 Goblet cell integrated density readings

\begin{tabular}{llll}
\hline & $\begin{array}{l}\text { Mean PAS at } \\
550 \mathrm{~nm}\end{array}$ & $\begin{array}{l}\text { Mean } A B \text { at } \\
610 \mathrm{~nm}\end{array}$ & No. \\
\hline Non-ulcer & $45 \cdot 0 \pm 2 \cdot 3$ SEM & $38 \cdot 9 \pm 2.5$ SEM & $\mathrm{n}=10$ \\
Ulcer & $44 \cdot 2 \pm 5 \cdot 4$ SEM & $29 \cdot 3 \pm 2 \cdot 4$ SEM & $\mathrm{n}=8$ \\
Healed & $45 \cdot 0 \pm 4 \cdot 8$ SEM & $35 \cdot 6 \pm 2.5$ SEM & $n=8$ \\
\hline
\end{tabular}

p PAS Non-ulcer: ulcer NS. Non-ulcer: healed NS. Ulcer: healed NS.

AB Non-ulcer: ulcer $p<() \cdot(2)$. Non-ulcer: healed NS. Ulcer: healed NS.
Table 2 Goblet cell count

\begin{tabular}{llll}
\hline & $\begin{array}{l}\text { Mean goblet cell } \\
\text { count } P A S\end{array}$ & $\begin{array}{l}\text { Mean goblet cell } \\
\text { count } A B\end{array}$ & No. \\
\hline Non-ulcer & $32 \cdot 3 \pm 3 \cdot 6$ SEM & $27 \cdot 3 \pm 2 \cdot 0$ SEM & $n=10$ \\
Ulcer & $10 \cdot 9 \pm 2 \cdot 5$ SEM & $14 \cdot 0 \pm 4 \cdot 8$ SEM & $n=8$ \\
Healed & $21 \cdot 0 \pm 4 \cdot 7$ SEM & $17 \cdot 1 \pm 2 \cdot 4$ SEM & $n=8$ \\
\hline
\end{tabular}

p PAS Non-ulcer: ulcer $p<0 .(0) 1$. Non-ulcer: healed NS. Ulcer: healed NS.

AB Non-ulcer: ulcer $p<() \cdot(25$. Non-ulcer: healed $p<0) \cdot 01$. Ulcer: healed NS

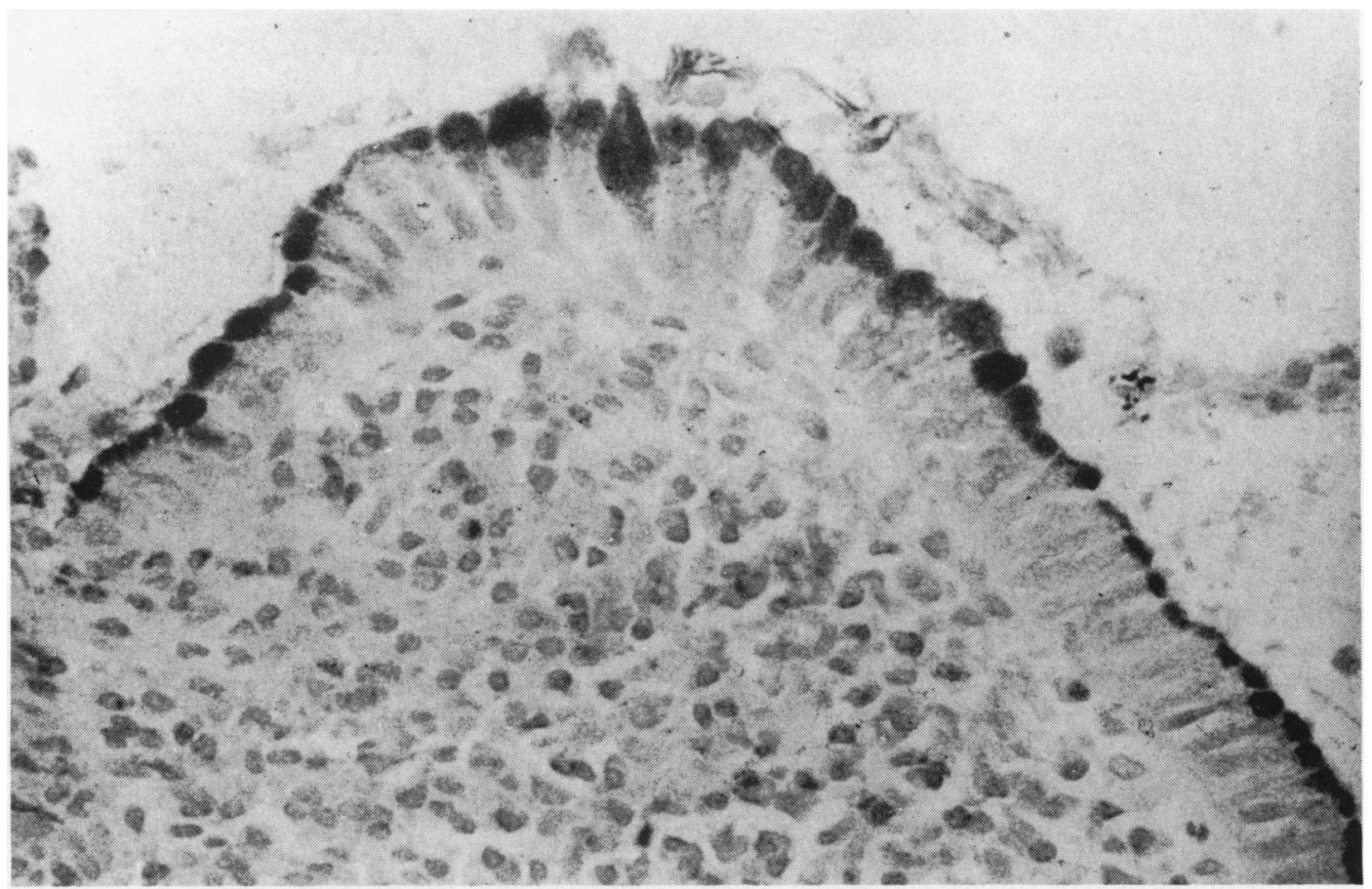

Fig. 2 Section of mucosa adjacent to duodenal ulceration showing severe cellular infiltration with disappearance of goblet cells and appearance of PAS stained surface epithelial cells. Alcian blue, PAS, and haematoxylin $\times 400$.

Table 3 Surface epithelium integrated density readings

\begin{tabular}{lll}
\hline & $\begin{array}{l}\text { Mean PAS at } \\
550 \mathrm{~nm}\end{array}$ & No. \\
\hline Non-ulcer & $20.0 \pm 8.0 \mathrm{SEM}$ & $\mathrm{n}=10$ (7 hhowed no staining) \\
Ulcer & $51 \cdot 5 \pm 9.0 \mathrm{SEM}$ & $\mathrm{n}=8$ (1 showed no staining) \\
Healed & $32.0 \pm 14 \cdot 0$ SEM & $\mathrm{n}=8$ (4 showed no staining) \\
\hline
\end{tabular}

p PAS Non-ulcer: ulcer $p<0 \cdot 02$. Non-ulcer: healed NS. Ulcer: healed NS.
Table 4 Length of PAS stained surface epithelium as a percentage of the total surface length

\begin{tabular}{|c|c|c|}
\hline & $\begin{array}{l}\text { Median \% of } \\
\text { surface length }\end{array}$ & No. \\
\hline $\begin{array}{l}\text { Non-ulcer } \\
\text { Ulcer } \\
\text { Healed }\end{array}$ & $\begin{array}{r}3 \cdot 8(\text { range } 2 \cdot 8-16 \cdot 8) \\
54 \cdot 0(\text { range } 3 \cdot 6-77 \cdot 1) \\
22 \cdot 8(\text { range } 0 \cdot 8-83 \cdot 4)\end{array}$ & $\begin{array}{l}n=10(7 \text { showed no staining }) \\
n=8(1 \text { showed no staining }) \\
n=8(4 \text { showed no staining })\end{array}$ \\
\hline
\end{tabular}




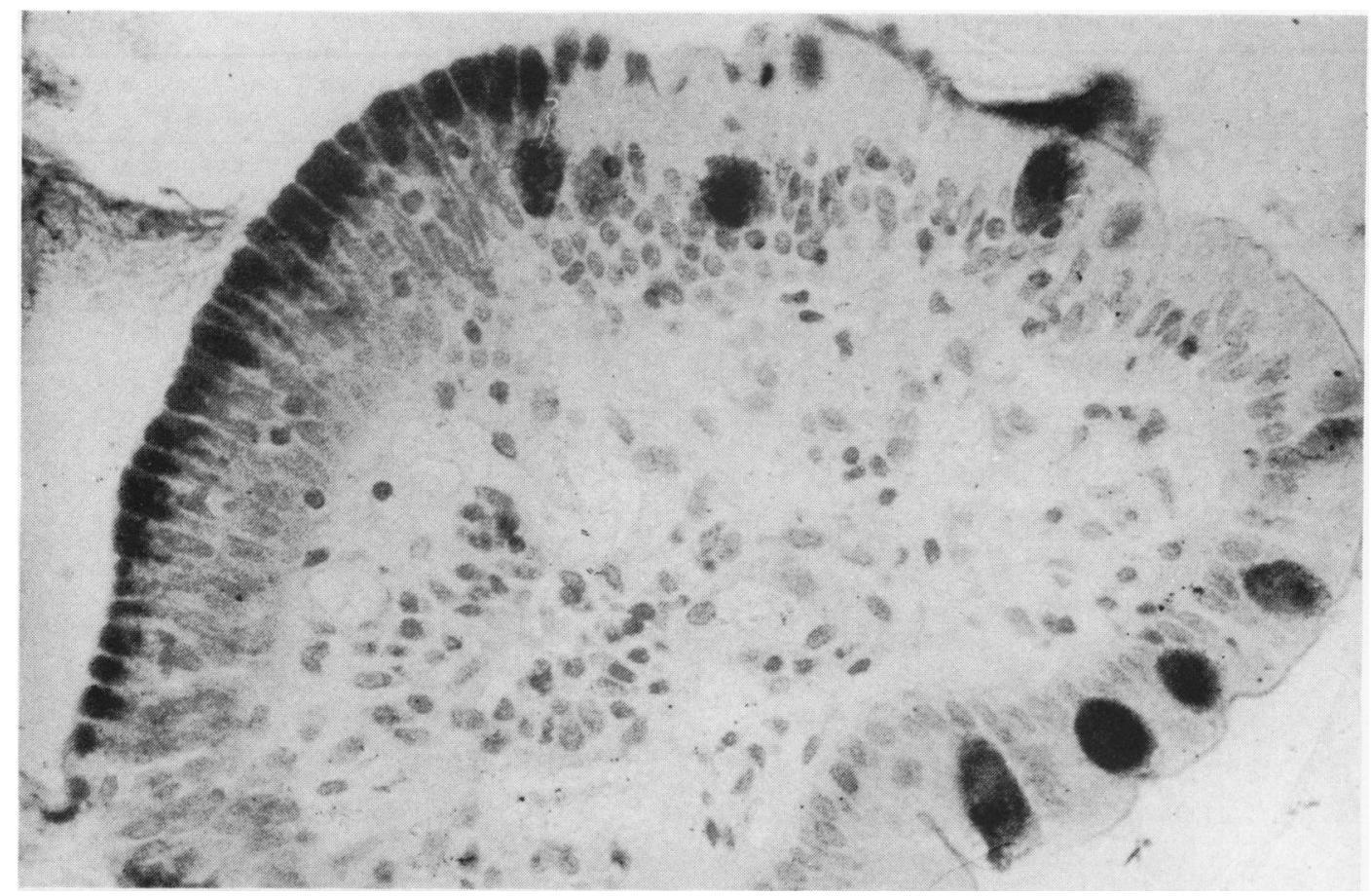

Fig. 3 Section of healed duodenal ulcer showing partial disappearance of PAS stained surface epithelial cells with normal goblet cells. Alcian blue, PAS and haematoxylin $\times 400$.

(Table 2) and correspondingly a greater part of the surface epithelium shows marked PAS staining. These changes are progressive during ulceration and return towards the normal in healing (Tables $1-4$ ). During healing there is an increase in goblet cell counts coinciding with the disappearance of surface PAS staining (Fig. 3). Florey and Harding ${ }^{15}$ had shown that artificial defects in the duodenal mucosa of cats healed by a simple mucous epithelium identical with gastric type surface epithelium. Later studies $^{16}$ in experiments on pigs found that many contiguous villi in duodenal loop fistulae were covered by mucus containing cells similar to those lining the stomach. This was in contrast with the normal pig duodenum.

The partial replacement of the normal epithelial cells of the human duodenal mucosa by epithelial cells containing mucus was described in 1964 by James. He had first noticed mucous changes in a biopsy of the second part of the duodenum in a patient thought to have the Zollinger-Ellison Syndrome. ${ }^{17}$ In accordance with James' findings ${ }^{17}$ we have found mucous cells near the tips and on the sides of the villi forming a characteristic grouping and containing PAS staining mucus. As ulceration proceeds the villi become stunted, goblet cells decreased and the surface epithelium PAS staining increased so that the whole of the surface becomes PAS positive. Patrick, Denham, and Forrest ${ }^{18}$ have carried out an extensive light and electron microscope study on mucous change in the human duodenum. They have correlated their findings to the incidence of peptic ulcer disease. They summarised their morphotopical findings and suggested that the mucous change is a protective mechanism involved in some way as yet unknown with the healing of ulcers.

Recent work by Gregory, Moshal, and Spitaels ${ }^{2}$ confirms these previous workers' findings. They suggest that the changes suggest a change towards an antral type of mucosa and are a protective response by the duodenum to exposure to an excess of acid and pepsin.

We are grateful to Charing Cross Hospital, Chelsea College, and Professor P Gahan at Queen Elizabeth College for the use of their Vickers M86 and Zeiss photomicroscopes. P M W was supported by a grant from Smith, Kline and French. 


\section{References}

1 Lev $R$. The mucin histochemistry of normal and neoplastic gastric mucosa. Lab Invest 1966; 14: 2080100.

2 Gregory MA, Moshal MG, Spitaels JM. Changes in the morphology of villar epithelial cells adjacent to duodenal ulcers during the process of healing. Scand $J$ Gastroenterol 1982; 17: 441-8.

3 James AH. Gastric epithelium in the duodenum. Gut 1964; 5: 285-94.

4 Morrissey SM, Tymvios M. Acid mucins in human intestinal goblet cells. J Pathol 1978; 126: 197-208.

5 Spicer SS, Meyer DB. Histochemical differentiation of acid mucopolysaccharides by means of combined aldehyde fuchsin - alcian blue staining. Am J Clin Pathol 1960; 33: 453-60.

6 Schrager J. Sulphated mucopolysaccharides of the gastric secretion. Nature (Lond) 1964; 201: 702-4.

7 Lev R, Spicer SS. A histochemical comparison of human epithelial mucins in normal and in hypersecretory states including pancreatic cystic fibrosis. Am $J$ Pathol 1965; 46: 23-47.

8 Gottschalk A. The chemistry and biology of Sialic Acid and related substances. London: Cambridge University Press, 1960.

9 Gibbons RA, Mattner P. Some aspects of cervical mucus. Proceedings of the $\mathrm{V}$ world congress on fertility and sterility. Exerpta Med International Congress Series 1966; 133: 695-700.

10 Lamb D, Reid L. Quantitative distribution of types of acid glycoproteins in mucous cells of human bronchi. Histochem J 1972; 4: 91-102.

11 Kent PW, Marsden JC. A sulphated sialoprotein from sheep's colonic mucin. Biochem J 1963; 87: 38-9.

12 Greco V, Lauro G, Fabbrini A, Torsoli A. Histochemistry of the colonic epithelial mucins in normal subjects and in patients with ulcerative colitis. Gut 1967; 8: 491-506.

13 Cathcart RS III, Fitts CT, McAlhany JC, Spicer SS. Histochemical changes in gastric mucosubstances in patients with acute and chronic ulcer disease. Ann Surg 1974; 180: 1-8.

14 Andre F, Bouhours D, Andre C, Descos F, Lambert R. The carbohydrate and ester sulphate content of mucosal biopsies in health and in patients with duodenal ulcer. Clin Chim Acta 1974; 56: 255-9.

15 Florey HW, Harding HE. The healing of artificial defects of the duodenal mucosa. J Pathol Bact 1935; 40: 211-8.

16 Florey HW, Jennings MA, Jennings DA, O'Conner RC. The reactions of the intestine of the pig to gastric juice. J Pathol Bact 1939; 49: 105-23.

17 James AH. Gastric epithelium in the duodenum of a patient with gastric hyperacidity. Proceedings of the 2nd World Congress of Gastroenterology, Munich 1962. Kargar, Basle and New York: 1963: 540-543.

18 Patrick WJA, Denham D, Forrest APM. Mucous change in the human duodenum. A light and electron microscopic study and correlation with disease and gastric acid secretion. Gut 1974; 15: 767-76. 